\title{
Application of aqueous carbonated slags in the immobilization of heavy metals in field-contaminated soils
}

\author{
Jiyeon Choi, Won Sik Shin ${ }^{\dagger}$ \\ School of Architecture, Civil, Environmental and Energy Engineering, Kyungpook National University, Daegu 41566, Republic of Korea
}

\begin{abstract}
The aqueous carbonation efficiencies of basic oxygen furnace (BOF) and ladle slags at various pressures, temperatures, and liquid-to-solid (L/S) ratios were investigated to determine optimum conditions. The maximum $\mathrm{CO}_{2}$ carbonated concentrations in slag $(0.584 \mathrm{mmol} / \mathrm{g}$ for $\mathrm{BOF}$ slag and $1.038 \mathrm{mmol} / \mathrm{g}$ for ladle slag) was obtained at $10 \mathrm{bars}, 40^{\circ} \mathrm{C}$, and $\mathrm{L} / \mathrm{S}=5 \mathrm{~mL} / \mathrm{g}$-dry. The L/S ratio was the most critical parameter for carbonation The effect of carbonated slag amendment on the immobilization of heavy metals in two field-contaminated soils was also investigated. The immobilization efficiencies evaluated by using the toxicity characteristic leaching procedure (TCLP) and the Standards, Measurements and Testing Programme (SM\&T) were above $90 \%$ for both raw and carbonated slags for all soils. The TCLP-extractable heavy metals concentrations were below the criteria (5.0, 1.0 and $5.0 \mathrm{~g} / \mathrm{L}$ for $\mathrm{Pb}, \mathrm{Cd}$, and $\mathrm{Cr}$, respectively) after immobilizations with both slags except for Pb in soil B. The SM\&T analysis showed the decrease in the exchangeable phase but the increase in residual phase after immobilization with raw and carbonated slags. The results of this study imply the promising potential of the carbonated slags on the immobilization of heavy metals in the field-contaminated soils.
\end{abstract}

Keywords: Aqueous carbonation, Contaminated soils, Heavy metals, Immobilization, Slag

\section{Introduction}

Slags are a mixture of silica, calcium oxide, magnesium oxide, aluminum oxide and iron oxide and classified into four types based on the production process used, i.e., blast furnace slag, basic oxygen furnace (BOF) slag, electric arc furnace slag, and ladle furnace slag $[1,2]$. Annually, more than 400 million tons of the slags are produced [3]. BOF slag is formed during moldering of iron into steel and ladle slag is a by-product of steel refining in both basic oxygen and/or electric arc furnaces [4].

Mineral carbonation is the reaction of metal oxides such as $\mathrm{Ca}, \mathrm{Fe}$, and $\mathrm{Mg}$ in materials with $\mathrm{CO}_{2}$ to form metal carbonate (Eq. (1)), in which Ca- and Mg-oxides react with $\mathrm{CO}_{2}$ and produce $\mathrm{CaCO}_{3}$ and $\mathrm{MgCO}_{3}[5,6]$. The mineral carbonation is divided into gas-solid carbonation and direct aqueous carbonation. Compared to gas-solid carbonation, the aqueous carbonation can reduce the energy requirement for carbonation with high carbonation efficiency [6-9].

$$
\text { Metal-oxide }+\mathrm{CO}_{2} \rightarrow \text { Metal-carbonate }+ \text { Heat }
$$

The carbonation can also occur depending on the content of Ca- and Mg-silicates such as calcium silicate $\left(\mathrm{Ca}_{2} \mathrm{SiO}_{3}\right)$ and magnesium silicate $\left(\mathrm{Mg}_{2} \mathrm{SiO}_{4}\right)$ in slags as shown in Eq. (2) and (3) [6, 10]. Bernal et al. [11, 12] investigated the natural carbonation of aged alkali-activated slag concretes. Several other researchers have worked the acceleration of aqueous carbonation of the steel-making slag [13], and the BOF slag using a rotating packed bed and the production of calcite (calcium carbonate, $\mathrm{CaCO}_{3}$ ) [7]. In addition, other parameters such as slag particle size, mineralogical characteristics, air pressure, $\mathrm{CO}_{2}$ concentration, temperature, and reaction time should be also considered to estimate the potential to the carbonation rate [8].

$$
\begin{gathered}
\mathrm{Ca}_{2} \mathrm{SiO}_{3}+\mathrm{CO}_{2}+2 \mathrm{H}_{2} \mathrm{O} \rightarrow \mathrm{CaCO}_{3}+\mathrm{H}_{4} \mathrm{SiO}_{4} \\
\mathrm{Mg}_{2} \mathrm{SiO}_{4}+2 \mathrm{CO}_{2}+2 \mathrm{H}_{2} \mathrm{O} \rightarrow 2 \mathrm{MgCO}_{3}+\mathrm{H}_{4} \mathrm{SiO}_{4}
\end{gathered}
$$

Many studies have been reported on the immobilization and stabilization of heavy metals with various kinds of binders such as cement, slag, lime and apatite [14-19]. Lee et al. [17] reported
This is an Open Access article distributed under the terms of the Creative Commons Attribution Non-Commercial License (http://creativecommons.org/licenses/by-nc/3.0/) which permits unrestricted non-commercial use, distribution, and reproduction in any medium, provided the original work is properly cited.

Copyright (C) 2020 Korean Society of Environmental Engineers
Received March 13, 2019 Accepted May 16, 2019

${ }^{\dagger}$ Corresponding author

Email: wshin@knu.ac.kr

Tel: +82-53-950-7584 Fax: +82-53-950-6579

ORCID: 0000-0001-6829-8825 
the good stabilization efficiency of Cd-, Pb- and Zn-contaminated soils with the furnace slag, decreasing the bioavailability of the heavy metals.

The leaching behavior of heavy metals may be related to the $\mathrm{pH}$ of slag. The $\mathrm{pH}$ buffering capacity of the slag related to hydroxide/carbonate buffering may decrease by carbonation. Kim et al. [16] reported that $\mathrm{pH}$ in carbonated slag paste can decrease, and the solubility of some heavy metals can increase. Conversely, Capobianco et al. [15] reported that the increase of the buffering capacity was observed with the high calcite content of the carbonated slag. Liu et al. [18] reported that the carbonation improved the immobilization efficiencies of heavy metals. The effectiveness of slag in heavy metals immobilization in contaminated soil has been reported in several studies [17, 20]. The effect of carbonation on the leaching characteristics of heavy metals in contaminated soil has been reported [18]. Carbonated slag with $\mathrm{CO}_{2}$ sequestered is expected to be effective in the stabilization of heavy metals in contaminated soils. Therefore, the effect of carbonation on the immobilization characteristics of heavy metals should be further investigated.

In the present work, the objective of this study is to investigate the effect of three operational parameters (pressure, temperature and liquid/solid (L/S) ratio) on the efficiency of aqueous carbonation of $\mathrm{BOF}$ and ladle slags for $\mathrm{CO}_{2}$ sequestration and the effect of the carbonation on immobilization efficiencies of heavy metals in contaminated soils.

\section{Materials and Methods}

\subsection{Chemicals}

Sodium acetate $\left(\mathrm{NaCH}_{3} \mathrm{COO}, 99 \%\right)$, isopropyl alcohol $\left(\mathrm{C}_{3} \mathrm{H}_{7} \mathrm{OH}\right.$, $70 \%$ ), ammonium acetate $\left(\mathrm{C}_{2} \mathrm{H}_{3} \mathrm{O}_{2} \mathrm{NH}_{4}, 95 \%\right)$, hydrochloric acid ( $\mathrm{HCl}, 35-37 \%)$, nitric acid $\left(\mathrm{HNO}_{3}, 70 \%\right)$, acetic acid $\left(\mathrm{CH}_{3} \mathrm{COOH}\right.$, 95\%), hydroxylamine hydrochloride $\left(\mathrm{HONH}_{2} \cdot \mathrm{HCl}, 95 \%\right)$, and ethanol $\left(\mathrm{C}_{2} \mathrm{H}_{5} \mathrm{OH}\right)$ were purchased from Duksan Pure Chemical, Korea, and hydrogen peroxide $\left(\mathrm{H}_{2} \mathrm{O}_{2}, 29-32 \%\right)$ was purchased from Alfa Aesar (MA, USA). Inductively coupled plasma multi-element standard solution IV was purchased from Merck, Germany.

\subsection{Slags}

BOF slag (POSCO Co., Pohang, Korea) and ladle slag (Hyundai Steel Co., Dangjin, Korea) were air-dried for $2 \mathrm{w}$, disaggregated, homogenized using a tumbler, sieved through a $595 \mu \mathrm{m}$ mesh (sieve \#30), and then stored in an airtight container before use.

Elemental compositions of raw and carbonated slags were analyzed using X-ray fluorescence (XRF, PW2400, Philips Electronic Instruments, Inc., the Netherlands), and mineral compositions were identified using X-ray diffraction (XRD, X'pert PRO MPD, PANalytical, the Netherlands). Sample morphologies were examined by ultra-high-resolution field-emission scanning electron microscopy (FE-SEM, S-4300, Hitachi, Japan), and surface areas and pore size distributions were characterized using a surface area and pore size analyzer (BET; Autosorb-iQ \& Quadrasorb SI, Quantachrome, USA). The content of calcium carbonate in raw and carbonated slags was quantified by thermogravimetric analysis
(TGA, Q500, TA Instruments, USA). A dried slag sample (50 mg) was heated from 25 to $1,000^{\circ} \mathrm{C}$ with a rate of $10^{\circ} \mathrm{C} / \mathrm{min}$ under nitrogen atmosphere. The $\mathrm{CO}_{2}$ uptake was determined by the mass loss during heating from 500 to $800^{\circ} \mathrm{C}$.

\subsection{Contaminated Soils}

Two different contaminated soils were used for immobilization experiments. Soil A (N 3651’55”, E $129^{\circ} 2^{\prime} 4^{\prime \prime}$ ) was collected from a abandoned mine located in Bonghwa-gun, Gyeongsang buk-do and soil B (N 36 4'49”, E $\left.126^{\circ} 00^{\prime} 27^{\prime \prime}\right)$ was collected from the closed Janghang metal refinery in Seocheon-gun, Chungcheong nam-do. Soils were air-dried for two weeks, disaggregated, sieved through sieve No. 30 (595 $\mu \mathrm{m})$, homogenized using a tumbler, and stored in a closed container prior to use as described elsewhere [14].

Heavy metals were extracted from soil samples by using microwave-assisted acid digestion with aqua regia solution to estimate background concentrations [21]. The concentrations of the extracted heavy metals were measured by an inductively coupled plasma optical emission spectroscopy (ICP-OES, Optima 2100 DV, Perkin Elmer Inc., USA).

The physicochemical properties of soils are summarized in Table S1. Soil A was identified as neutral ( $\mathrm{pH}$ 6.75), while soil B was moderately acidic ( $\mathrm{pH}$ 5.7). The cation exchange capacity of soils $\mathrm{A}$ and $\mathrm{B}$ were 17.05 and $11.95 \mathrm{meq} / 100 \mathrm{~g}$ and the organic carbon contents were 0.77 and $0.44 \%$, respectively. The background heavy metals concentrations in soil B were higher than soil A. Especially soil B was heavily contaminated with $\mathrm{Pb}(122,200 \mathrm{mg} / \mathrm{kg})$ and Zn $(17,520 \mathrm{mg} / \mathrm{kg})$. Other heavy metals such as $\mathrm{Cd}$, Cr, and $\mathrm{Ni}$ were not detected.

\subsection{Aqueous Carbonation}

The carbonation was conducted by preparing $100 \mathrm{~g}$ slags into a closed stainless steel reactor equipped with u-shape impeller and pure $\mathrm{CO}_{2}$ gas (PS Chem. Co., Gimhae, Korea). Gas in aluminum supply vessel is supplied into the reactor for a constant pressure condition by a differential pressure between reactor and supply vessel. The volumes of the reactor and the supply vessel were 256.4 and $571.3 \mathrm{~cm}^{3}$, respectively. The temperatures in the reactor and supply vessel were controlled by immersing them in a water:ethanol $(7: 3, v / v)$ bath. The temperatures and pressures in the reactor and supply vessel were recorded automatically every 30 s using a data acquisition system (Converter RS485-RS232C, Sejinyoung Tech, Korea).

The aqueous carbonation experiments were carried out under several conditions such as i) different pressures $(1,5$, and 10 bar) at $25^{\circ} \mathrm{C}$ with an $\mathrm{L} / \mathrm{S}$ ratio of $5 \mathrm{~mL} / \mathrm{g}$-dry, ii) different temperatures $\left(1,25\right.$, and $\left.40^{\circ} \mathrm{C}\right)$ with 10 bar and $\mathrm{L} / \mathrm{S}$ ratio of $5 \mathrm{~mL} / \mathrm{g}$-dry, and iii) different $\mathrm{L} / \mathrm{S}$ ratios $\left(1,2\right.$, and $5 \mathrm{~mL} / \mathrm{g}$-dry) with $40^{\circ} \mathrm{C}$ and 10 bar, respectively.

After carbonation, the mixtures of slag and water were separated by centrifugation at $3,000 \mathrm{rpm}$ and dried in an oven at $60^{\circ} \mathrm{C}$. The following equation was used to calculate the $\mathrm{CO}_{2}$ uptake of slag [22]:

$$
n_{C O_{2}}(t)=\left(\frac{P_{0}}{z_{0} R T_{0}}-\frac{P(t)}{z(t) R T(t)}\right) V_{R}
$$


where $n_{\mathrm{CO}_{2}}(t)$ is the mole number of $\mathrm{CO}_{2}$ reduced in the slag-water mixture (mol), $P_{0}$ and $P(t)$ are pressures $(\mathrm{kPa})$ at time 0 and $t$, respectively, $R$ is the gas constant $\left(8,314 \mathrm{~cm}^{3} \mathrm{kPa} / \mathrm{mol} / \mathrm{K}\right), T_{0}$ and $T(t)$ are temperatures $(\mathrm{K})$ at time 0 and $t$, respectively, $z_{0}$ and $z(t)$ are real-gas compressibility factors at time 0 and $t$, respectively, and $V_{R}$ is the reactor volume $\left(571.3 \mathrm{~cm}^{3}\right)$.

The carbonated $\mathrm{CO}_{2}$ concentration in slag at time $t\left(q_{\mathrm{CO}_{2}}(t)\right.$, mmol CO $2 / g$ slag) is calculated from $n_{\mathrm{CO}_{2}}(t)$ (mol) in Eq. (4) multiplied by thousand $(1,000 \mathrm{mmol} / \mathrm{mol})$ divided by slag weight $(100$ g). The $q_{\mathrm{CO}_{2}}(t)$ data were fitted to a pseudo-first-order kinetic model (PFOKM) and a pseudo-second-order kinetic model (PSOKM) to estimate the maximum carbonation capacity (mmol/g) [10, 23-25], as described below:

$$
\begin{gathered}
q_{\mathrm{CO}_{2}}(t)=q_{\mathrm{CO}_{2}, m 1}\left(1-e^{-k_{1} t}\right) \\
q_{\mathrm{CO}_{2}}(t)=\frac{t}{1 /\left(k_{2} q_{C O_{2}, m 2}^{2}\right)+t / q_{\mathrm{CO}_{2} \cdot m 2}}
\end{gathered}
$$

where $q_{\mathrm{CO}_{2}, \mathrm{~m} 1}$ in Eq. (5) and $q_{\mathrm{CO}_{2}, \mathrm{~m} 2}$ in Eq. (6) are the maximum carbonated $\mathrm{CO}_{2}$ capacity in slag at equilibrium (mmol/g) for PFOKM and PSOKM, respectively, and $k_{1}(1 / \mathrm{min})$ and $k_{2}(\mathrm{~g} / \mathrm{mmol} / \mathrm{min})$ are the rate constants of carbonation for PFOKM and PSOKM, respectively. The $1 /\left(k_{2} q_{\mathrm{CO}_{2} \cdot m 2}\right)$ in the denominator of Eq. (6) is defined as the half-carbonation time $\left(t_{1 / 2}, \mathrm{~min}\right)$ with the initial rate of $\mathrm{CO}_{2}$ uptake $\left(r_{0}, \mathrm{mmol} / \mathrm{g} / \mathrm{min}\right)$ defined as:

$$
r_{0}=\frac{q_{C O_{2}, m 2}}{t_{1 / 2}}
$$

Model parameters were estimated by nonlinear regression using a commercial software package, TableCurve $2 \mathrm{D}^{\circledR}$ (Version 5.1, SYSTAT Software, Inc.).

\subsection{Acid Neutralizing Capacity (ANC) of Slags}

ANC is the ability of a sample to maintain a certain $\mathrm{pH}$ during acid treatment [26] The ANC was used to assess the effects of carbonation [27]. ANC tests were performed to support the $\mathrm{CO}_{2}$ carbonation efficiencies for both raw and carbonated slags. Briefly, $1 \mathrm{~g}$ slag sample was mixed with $100 \mathrm{~mL}$ of distilled water in an Erlenmeyer flask, and $1 \mathrm{M} \mathrm{HNO}_{3}(0.5 \mathrm{~mL})$ was added to the mixture every $24 \mathrm{~h}$ until $\mathrm{pH}$ was reached to be 8.2 . Subsequently, the flasks were sealed to prevent any further contact of the solution with atmospheric $\mathrm{CO}_{2}$, and the $\mathrm{pH}$ was checked by a $\mathrm{pH}$ meter (ORION 3-Star, Thermo Scientific ${ }^{\mathrm{TM}}$, USA).

\subsection{Immobilization of Heavy Metals with Raw and Carbonated Slags}

Immobilization of heavy metals in the contaminated soils with the raw and carbonated slags was conducted. Subsamples of slags (0.1, 0.3 , or $1.0 \mathrm{~g}$ ) were thoroughly mixed with $1.0 \mathrm{~g}$ of soil for 20 s using a vortex mixer (M37610-33, Thermo Scientific ${ }^{\mathrm{TM}}$, USA). The mixtures were diluted with distilled water to 50 wt.\% and allowed to stand for $24 \mathrm{~h}$ at room temperature [28] before the leaching test.

\subsection{Analysis of Extractable Heavy Metals Concentrations in Soils}

To measure the extractable concentrations of heavy metals in the soils with or without immobilization treatment with raw or carbonated slags, the toxicity characteristic leaching procedure (TCLP, USEPA, Method 1311) [29] and the Standards, Measurements and Testing Programme (SM\&T, formerly BCR) [30, 31] were applied.

For TCLP, $1.0 \mathrm{~g}$ soil sample was extracted for $18 \mathrm{~h}$ with 20 $\mathrm{mL}$ of the acetic acid $(0.57 \%, \mathrm{v} / \mathrm{v})$. The mixture was centrifuged for 20-min at 1,500 rpm and the supernatant was filtered through a $0.2-\mu \mathrm{m}$ syringe filter (Whatman, cellulose nitrate membrane, $\phi=25 \mathrm{~mm}$ ). The heavy metals concentrations in the supernatant were analyzed by using the ICP-OES.

The SM\&T procedure consists of three steps of extractions such as acetic acid extraction (exchangeable phase, step 1), hydroxylamine hydrochloride extraction (reducible phase, step 2), and ammonium acetate extraction (oxidizable phase, step 3). After finishing each step, the mixtures were centrifuged for $10 \mathrm{~min}$ at 1,500 $\mathrm{rpm}$, and the residues were washed with distilled water before using them for the next steps. The supernatants from each step were analyzed by the ICP-OES.

\subsection{Quality Assurance and Quality Control $(Q A / Q C)$}

Compliance with quality assurance and quality control (QA/QC) guidelines was achieved by performing two consecutive measurements to determine average values and relative standard deviations (RSDs). The above RSDs for $\mathrm{Pb}, \mathrm{Cd}, \mathrm{Cr}, \mathrm{Cu}, \mathrm{Zn}$, and Ni equaled $1.05,0.83,0.70,1.47,0.86$ and 0.40 , respectively, and the standard calibration slope was verified by performing standard solution measurements every 20 samples [24].

\section{Results and Discussion}

\subsection{Effect of Pressure, Temperature and L/S Ratio on $\mathrm{CO} 2$ Carbonation Rate}

The effects of pressure, temperature, and L/S ratio on aqueous carbonation kinetics were investigated. Several operating conditions such as 1,5 , and 10 bar for pressure, 1,25 , and $40^{\circ} \mathrm{C}$ to investigate effect of temperature and 1, 2, and $5 \mathrm{~mL} / \mathrm{g}$-dry of $\mathrm{L} / \mathrm{S}$ ratios were tested to draw optimum conditions.

As shown in Fig. S1, the carbonated $\mathrm{CO}_{2}$ concentration, $q_{\mathrm{CO}_{2}}(t)$ increased with time and then remained steady at equilibrium. The carbonation data were fitted to the PFOKM and PSOKM as the results were summarized in Table 1, respectively. In terms of $R^{2}$ values, the PSOKM $\left(R^{2}=0.866-0.998\right)$ fitted the $\mathrm{CO}_{2}$ carbonation data better than PFOKM $\left(R^{2}=0.709-0.990\right)$ for all slags.

The pseudo-first-order rate constant $\left(k_{1}, \mathrm{~min}^{-1}\right)$ for aqueous carbonation of BOF and ladle slags increased with pressure, temperature, and L/S ratio except for ladle slag at $P=10 \mathrm{bar}$ and $\mathrm{L} / \mathrm{S}$ $=5 \mathrm{~mL} / \mathrm{g}$-dry. The maximum capacity of $\mathrm{CO}_{2}$ carbonation $\left(q_{\mathrm{CO}_{2}, m 1}\right)$ in PFOKM at equilibrium increased with pressure, temperature, 
Table 1. PFOKM and PSOKM Parameters for Carbonation Kinetics of BOF and Ladle Slag at Different Pressure, Temperature and L/S Ratio

\begin{tabular}{|c|c|c|c|c|c|c|c|c|c|c|c|}
\hline & & \multicolumn{4}{|c|}{ PFOKM } & \multicolumn{6}{|c|}{ PSOKM } \\
\hline & & $\begin{array}{c}q_{C O_{2} \cdot m 1} \\
(\mathrm{mmol} / \mathrm{g})\end{array}$ & $\underset{(1 / \mathrm{min})}{\mathbf{k}_{1}}$ & $\mathbf{R}^{2}$ & SSE & $\begin{array}{c}q_{C O_{2} \cdot m 2} \\
(\mathrm{mmol} / \mathrm{g})\end{array}$ & $\begin{array}{c}\mathbf{k}_{2} \\
(\mathrm{~g} / \mathrm{mmol} / \mathrm{min})\end{array}$ & $\begin{array}{c}\mathbf{t}_{1 / 2} \\
(\mathrm{~min})\end{array}$ & $\underset{(\mathrm{mmol} / \mathrm{g} / \mathrm{min})}{\mathbf{r}_{0}}$ & $\mathbf{R}^{2}$ & SSE \\
\hline \multicolumn{12}{|c|}{$\mathrm{P}$ (bar); $\mathrm{T}=25^{\circ} \mathrm{C}, \mathrm{L} / \mathrm{S}$ ratio $=5 \mathrm{~mL} / \mathrm{g}$-dry } \\
\hline \multirow[t]{3}{*}{$\mathrm{BOF}$} & 1 & $\begin{array}{c}0.3851 \pm \\
0.0014\end{array}$ & $\begin{array}{c}0.0316 \pm \\
0.0006\end{array}$ & 0.9902 & 0.0046 & $\begin{array}{c}0.4315 \pm \\
0.0057\end{array}$ & $\begin{array}{c}0.1018 \pm \\
0.0089\end{array}$ & 22.76 & 0.0190 & 0.9520 & 0.0228 \\
\hline & 5 & $\begin{array}{c}0.4344 \pm \\
0.0046\end{array}$ & $\begin{array}{c}0.0550 \pm \\
0.0046\end{array}$ & 0.8376 & 0.0596 & $\begin{array}{c}0.4691 \pm \\
0.0039\end{array}$ & $\begin{array}{c}0.1829 \pm \\
0.0137\end{array}$ & 11.66 & 0.0402 & 0.9518 & 0.0177 \\
\hline & 10 & $\begin{array}{c}0.4945 \pm \\
0.0060\end{array}$ & $\begin{array}{c}0.0518 \pm \\
0.0048\end{array}$ & 0.7903 & 0.0993 & $\begin{array}{c}0.5343 \pm \\
0.0054\end{array}$ & $\begin{array}{c}0.1551 \pm \\
0.0141\end{array}$ & 12.07 & 0.0443 & 0.9278 & 0.0342 \\
\hline \multirow[t]{3}{*}{ Ladle } & 1 & $\begin{array}{c}0.6657 \pm \\
0.0057\end{array}$ & $\begin{array}{c}0.0134 \pm \\
0.0004\end{array}$ & 0.9866 & 0.0230 & $\begin{array}{c}0.8351 \pm \\
0.0047\end{array}$ & $\begin{array}{c}0.0166 \pm \\
0.0004\end{array}$ & 72.24 & 0.0116 & 0.9978 & 0.0038 \\
\hline & 5 & $\begin{array}{c}0.6864 \pm \\
0.0106\end{array}$ & $\begin{array}{c}0.0249 \pm \\
0.0019\end{array}$ & 0.8313 & 0.2016 & $\begin{array}{c}0.7716 \pm \\
0.0123\end{array}$ & $\begin{array}{c}0.0483 \pm \\
0.0048\end{array}$ & 26.81 & 0.0288 & 0.9231 & 0.0919 \\
\hline & 10 & $\begin{array}{c}0.8211 \pm \\
0.0072\end{array}$ & $\begin{array}{c}0.0412 \pm \\
0.0024\end{array}$ & 0.9117 & 0.1288 & $\begin{array}{c}0.8952 \pm \\
0.0047\end{array}$ & $\begin{array}{c}0.0734 \pm \\
0.0031\end{array}$ & 15.21 & 0.0589 & 0.9850 & 0.0218 \\
\hline \multicolumn{12}{|c|}{$\mathrm{T}\left({ }^{\circ} \mathrm{C}\right) ; \mathrm{P}=10 \mathrm{bar}, \mathrm{L} / \mathrm{S}$ ratio $=5 \mathrm{~mL} /$ g-dry } \\
\hline \multirow[t]{3}{*}{$\mathrm{BOF}$} & 1 & $\begin{array}{c}0.3231 \pm \\
0.0028\end{array}$ & $\begin{array}{c}0.0548 \pm \\
0.0037\end{array}$ & 0.8955 & 0.0216 & $\begin{array}{c}0.3483 \pm \\
0.0020\end{array}$ & $\begin{array}{c}0.2491 \pm \\
0.0132\end{array}$ & 11.53 & 0.0302 & 0.9765 & 0.0049 \\
\hline & 25 & $\begin{array}{c}0.4945 \pm \\
0.0060\end{array}$ & $\begin{array}{c}0.0518 \pm \\
0.0048\end{array}$ & 0.7903 & 0.0993 & $\begin{array}{c}0.5343 \pm \\
0.0054\end{array}$ & $\begin{array}{c}0.1551 \pm \\
0.0141\end{array}$ & 12.07 & 0.0443 & 0.9278 & 0.0342 \\
\hline & 40 & $\begin{array}{c}0.5481 \pm \\
0.0042\end{array}$ & $\begin{array}{c}0.0707 \pm \\
0.0049\end{array}$ & 0.8980 & 0.0527 & $\begin{array}{c}0.5835 \pm \\
0.0027\end{array}$ & $\begin{array}{c}0.1977 \pm \\
0.0094\end{array}$ & 8.67 & 0.0673 & 0.9809 & 0.0099 \\
\hline \multirow[t]{3}{*}{ Ladle } & 1 & $\begin{array}{c}0.4898 \pm \\
0.0078\end{array}$ & $\begin{array}{c}0.0414 \pm \\
0.0044\end{array}$ & 0.7090 & 0.1522 & $\begin{array}{c}0.5363 \pm \\
0.0085\end{array}$ & $\begin{array}{c}0.1203 \pm \\
0.0151\end{array}$ & 15.51 & 0.0346 & 0.8657 & 0.0702 \\
\hline & 25 & $\begin{array}{c}0.8211 \pm \\
0.0072\end{array}$ & $\begin{array}{c}0.0412 \pm \\
0.0024\end{array}$ & 0.9117 & 0.1288 & $\begin{array}{c}0.8952 \pm \\
0.0047\end{array}$ & $\begin{array}{c}0.0734 \pm \\
0.0031\end{array}$ & 15.21 & 0.0589 & 0.9850 & 0.0218 \\
\hline & 40 & $\begin{array}{c}0.9331 \pm \\
0.0078\end{array}$ & $\begin{array}{c}0.0327 \pm \\
0.0016\end{array}$ & 0.9396 & 0.1335 & $\begin{array}{c}1.0380 \pm \\
0.0047\end{array}$ & $\begin{array}{c}0.0464 \pm \\
0.0014\end{array}$ & 20.77 & 0.0500 & 0.9925 & 0.0166 \\
\hline \multicolumn{12}{|c|}{$\mathrm{L} / \mathrm{S}$ ratio $\left(\mathrm{mL} / \mathrm{g}\right.$-dry); $\mathrm{P}=10 \mathrm{bar}, \mathrm{T}=40^{\circ} \mathrm{C}$} \\
\hline \multirow[t]{3}{*}{$\mathrm{BOF}$} & 1 & $\begin{array}{c}0.5210 \pm \\
0.0046\end{array}$ & $\begin{array}{c}0.0679 \pm \\
0.0052\end{array}$ & 0.8937 & 0.0619 & $\begin{array}{c}0.5579 \pm \\
0.0059\end{array}$ & $\begin{array}{c}0.1860 \pm \\
0.0195\end{array}$ & 9.64 & 0.0579 & 0.9211 & 0.0459 \\
\hline & 2 & $\begin{array}{c}0.4965 \pm \\
0.0047\end{array}$ & $\begin{array}{c}0.1272 \pm \\
0.0147\end{array}$ & 0.7985 & 0.0712 & $\begin{array}{c}0.5207 \pm \\
0.0038\end{array}$ & $\begin{array}{c}0.3694 \pm \\
0.0365\end{array}$ & 5.20 & 0.1002 & 0.9277 & 0.0255 \\
\hline & 5 & $\begin{array}{c}0.5481 \pm \\
0.0042\end{array}$ & $\begin{array}{c}0.0707 \pm \\
0.0049\end{array}$ & 0.8980 & 0.0527 & $\begin{array}{c}0.5835 \pm \\
0.0027\end{array}$ & $\begin{array}{c}0.1977 \pm \\
0.0094\end{array}$ & 8.67 & 0.0673 & 0.9809 & 0.0099 \\
\hline \multirow[t]{3}{*}{ Ladle } & 1 & $\begin{array}{c}0.6976 \pm \\
0.0067\end{array}$ & $\begin{array}{c}0.0279 \pm \\
0.0014\end{array}$ & 0.9316 & 0.0881 & $\begin{array}{c}0.7848 \pm \\
0.0051\end{array}$ & $\begin{array}{c}0.0512 \pm \\
0.0021\end{array}$ & 24.91 & 0.0315 & 0.9869 & 0.0169 \\
\hline & 2 & $\begin{array}{c}0.6734 \pm \\
0.0070\end{array}$ & $\begin{array}{c}0.0383 \pm \\
0.0025\end{array}$ & 0.8836 & 0.1181 & $\begin{array}{c}0.7391 \pm \\
0.0059\end{array}$ & $\begin{array}{c}0.0805 \pm \\
0.0049\end{array}$ & 16.82 & 0.0439 & 0.9682 & 0.0322 \\
\hline & 5 & $\begin{array}{c}0.9331 \pm \\
0.0078\end{array}$ & $\begin{array}{c}0.0327 \pm \\
0.0016\end{array}$ & 0.9396 & 0.1335 & $\begin{array}{c}1.0380 \pm \\
0.0047\end{array}$ & $\begin{array}{c}0.0464 \pm \\
0.0014\end{array}$ & 20.77 & 0.0500 & 0.9925 & 0.0166 \\
\hline
\end{tabular}

and $\mathrm{L} / \mathrm{S}$ ratio for both BOF and ladle slags, except for BOF slag at $\mathrm{L} / \mathrm{S}=2 \mathrm{~mL} / \mathrm{g}$-dry, $P=10 \mathrm{bar}$, and $T=40^{\circ} \mathrm{C}$. The $q_{C O_{2}, m 1}$ values of ladle slag were consistently higher than those of BOF slag.

The maximum capacity of $\mathrm{CO}_{2}$ carbonation $\left(q_{\mathrm{CO}_{2}, \mathrm{~m} 2}\right)$ in PSOKM also increased with pressure, temperature, and L/S ratio for both BOF and ladle slags (Table 1). The highest $q_{\mathrm{CO}_{2}, \mathrm{~m} 2}$ value of ladle slag (1.0380 mmol/g) obtained at $10 \mathrm{bar}, 40^{\circ} \mathrm{C}$ and $\mathrm{L} / \mathrm{S}=5 \mathrm{~mL} / \mathrm{g}$-dry was higher than that of BOF slag $(0.5835 \mathrm{mmol} / \mathrm{g})$. On the contrary, the carbonation rates of $\mathrm{CO}_{2}$ into BOF slag was faster than those into ladle slag. The highest pseudo-second-order rate constants $\left(k_{2}, \mathrm{~mol}^{-1} \mathrm{~min}^{-1}\right)$ for BOF and ladle slags were 0.3694 and 0.1203 $\mathrm{g} / \mathrm{mmol} / \mathrm{min}$ obtained at $T=40^{\circ} \mathrm{C}, P=10 \mathrm{bar}$ and $\mathrm{L} / \mathrm{S}=2$ $\mathrm{mL} / \mathrm{g}$-dry and at $T=1^{\circ} \mathrm{C}, P=10$ bar and L/S $=5 \mathrm{~mL} / \mathrm{g}$-dry, respectively. The $k_{2}$ value was not correlated with pressure, temperature, and $\mathrm{L} / \mathrm{S}$ ratio, however, the $k_{2}$ and initial carbonation 

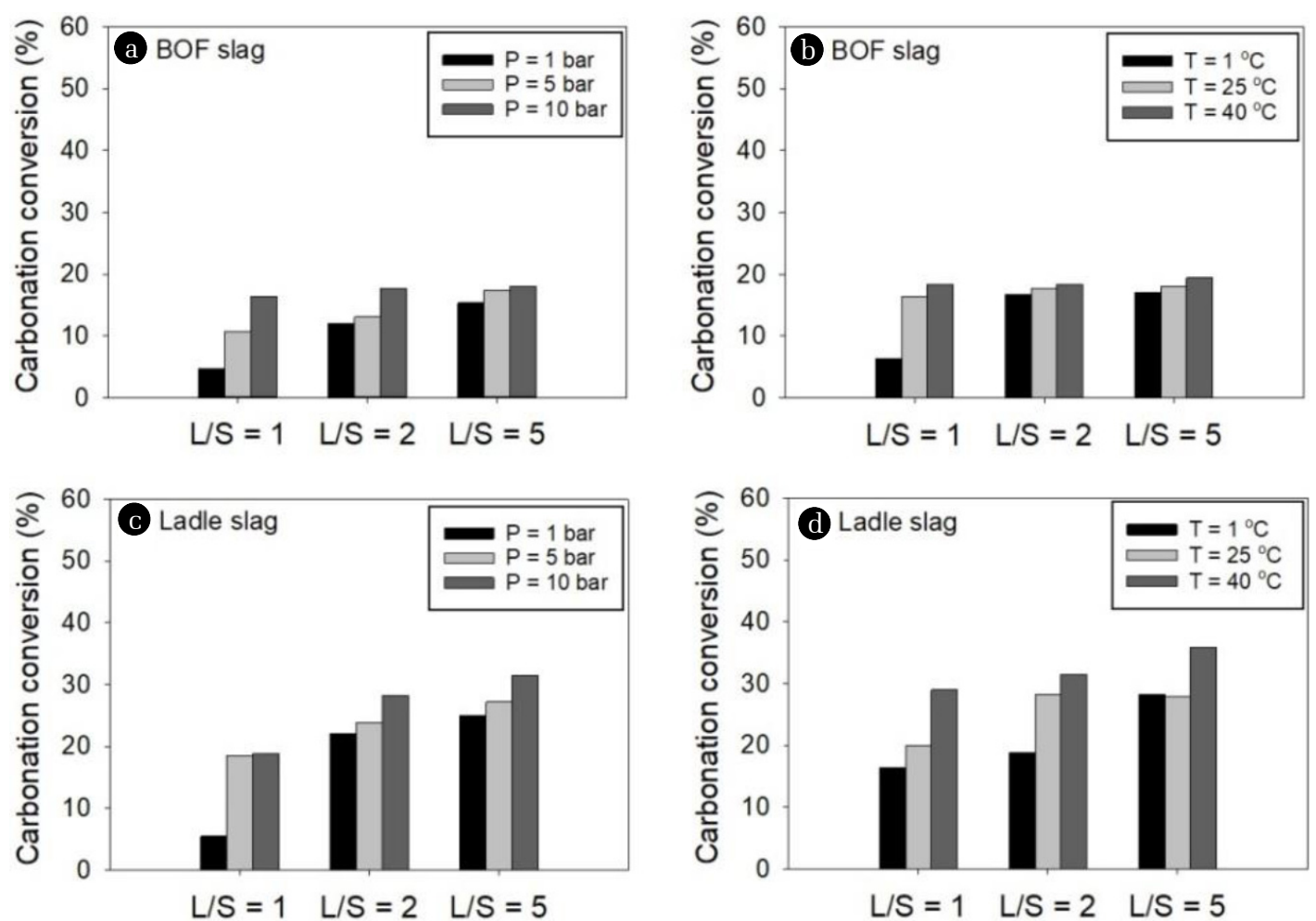

Fig. 1. The carbonation conversion results; the effect of pressure and $\mathrm{L} / \mathrm{S}$ ratio, at $\mathrm{T}=25^{\circ} \mathrm{C}$, to carbonation of (a) $\mathrm{BOF}$ slag (b) ladle slag, and the effect of temperature and L/S ratio, at $\mathrm{P}=10$ bar to carbonation of (c) BOF slag (b) ladle slag.

rate $\left(r_{0}\right)$ of BOF slag were higher than those of ladle slag at all conditions.

Fig. 1 shows that the carbonation conversion ratio (\%), a ratio of the carbonated $\mathrm{CO}_{2}$ into slags from the injected $\mathrm{CO}_{2}$ gas, increases with pressure, temperature, and L/S ratio for both BOF and ladle slags, which was in agreement with other researches [8, 13, 32]. Polettini et al. [8] and Ukwattage et al. [13] reported that the rate of carbonation is enhanced up to $50^{\circ} \mathrm{C}$ due to Ca leaching that was probably the rate-determining reaction step at below $50^{\circ} \mathrm{C}$. In this study, the $\mathrm{L} / \mathrm{S}$ ratio played more import role than the pressure and temperature in determining carbonation efficiency of BOF and ladle slags. This is because the high L/S ratio can increase hydration and dissolution of $\mathrm{Ca}$ and $\mathrm{CO}_{2}$ in aqueous phase [33], as indicated by Eq. (1)-(3), thereby increasing $\mathrm{CO}_{2}$ sequestration.

\subsection{Comparison of Physicochemical Characteristics of Raw and Carbonated Slags}

The BET surface area, pore volume, pore size and the results of XRF analysis for raw and carbonated slags were listed in Table 2. In comparison of Table 1 and 2, the maximum capacities of $\mathrm{CO}_{2}$ carbonation $\left(q_{\mathrm{CO}_{2}, m 1}\right.$ and $\left.q_{\mathrm{CO}_{2}, m 2}\right)$ in ladle slag were higher than those in BOF slag, it can be attributed to the specific surface area, pore volume, pore size, and $\mathrm{Ca}$ and $\mathrm{Mg}$ contents of slags. Ukwattage et al. [13] and Salman et al. [34] also reported the same conclusion that $\mathrm{CO}_{2}$ sequestration capacity is directly dependent on the proportions of binary oxides ( $\mathrm{CaO}$ and $\mathrm{MgO})$ and/or hydroxides $\left(\mathrm{Ca}(\mathrm{OH})_{2}\right.$ and $\left.\mathrm{Mg}(\mathrm{OH})_{2}\right)$ in the matrix. Pan et al. [7] and Ko et al. [35] emphasized that the hydration of $\mathrm{Ca}^{2+}$ and $\mathrm{Mg}^{2+}$ in steel slags during carbonation is important to for accomplish high $\mathrm{CO}_{2}$ reactivity and capture capacity. Baciocchi et al. [36] and Boone et al. [37] reported that the higher specific surface enhances the reactivity of slags with $\mathrm{CO}_{2}$, and the greater pore volume and pore size increase the capacity for carbonated mineral precipitates.

Fig. 2 shows the XRD analyses for raw and carbonated slags. The main crystal phases of BOF and ladle slags were quartz $\left(\mathrm{SiO}_{2}\right.$, Q) and dicalcium silicate $\left(\mathrm{Ca}_{2} \mathrm{SiO}_{4}, \mathrm{D}\right)$, respectively. The BOF slag also contains calcite $\left(\mathrm{CaCO}_{3}, \mathrm{C}\right)$ and calcium hydroxide $\left(\mathrm{Ca}(\mathrm{OH})_{2}\right.$, $\mathrm{H}$ ), and the ladle slag has calcite $(\mathrm{C})$, brucite $\left(\mathrm{Mg}(\mathrm{OH})_{2}, \mathrm{~B}\right)$, and katoite $\left(\mathrm{Ca}_{3} \mathrm{Al}_{2}(\mathrm{OH})_{12}, \mathrm{~K}\right)$. However, no $\mathrm{Mg}$ was detected in $\mathrm{BOF}$ slag as examined by XRD as well as XRF analysis (Table 2). After carbonation, the peak of calcium hydroxide $\left(\mathrm{Ca}(\mathrm{OH})_{2}, \mathrm{H}\right)$ in $\mathrm{BOF}$ slag disappeared and the peak area of the dicalcium silicate $\left(\mathrm{Ca}_{2} \mathrm{SiO}_{4}, \mathrm{D}\right)$ in ladle slag decreased, whereas the intensity of the calcite $\left(\mathrm{CaCO}_{3}, \mathrm{C}\right)$ peaks in $\mathrm{BOF}$ and ladle slags remarkably increased.

The decomposition of hydrates and carbonates in slags was investigated by the thermogravimetric analysis (TGA). Fig. 3 shows that decomposition of hydrates can be divided into three weight loss fractions, assigned to (i) moisture loss at $25-105^{\circ} \mathrm{C}$, (ii) organic carbon oxidation and $\mathrm{MgCO}_{3}$ decomposition at $105-500^{\circ} \mathrm{C}$, and (iii) $\mathrm{CaCO}_{3}$ decomposition at $500-780^{\circ} \mathrm{C}$ [38]. The mass loss of $\mathrm{CaCO}_{3}$ in raw and carbonated $\mathrm{BOF}$ slags at $500-780^{\circ} \mathrm{C}$ was about $7 \%$ and $16 \%$, while that of ladle slag was $3.7 \%$ and $13 \%$, 
Table 2. The Characteristics of Raw and Carbonated Slags

\begin{tabular}{|c|c|c|c|c|}
\hline \multirow{2}{*}{$\begin{array}{l}\text { Slags properties } \\
\text { Surface analysis }\end{array}$} & \multicolumn{2}{|c|}{ Raw slag } & \multicolumn{2}{|c|}{ Carbonated slag } \\
\hline & BOF & Ladle & BOF & Ladle \\
\hline $\mathrm{N}_{2}$ BET surface area $\left(\mathrm{m}^{2} / \mathrm{g}\right)$ & 5.66 & 37.96 & 9.82 & 5.58 \\
\hline Pore volume $\left(\mathrm{cm}^{3} \mathrm{~g}^{-1}\right)$ & 0.026 & 0.050 & 0.042 & 0.007 \\
\hline Pore size $(\AA)$ & 18.60 & 21.30 & 18.72 & 21.03 \\
\hline \multicolumn{5}{|l|}{ XRF analysis (elements, wt.\%) } \\
\hline $\mathrm{Mg}$ & - & 5.40 & 1.0 & 4.2 \\
\hline $\mathrm{Al}$ & 0.72 & 6.20 & 1.1 & 6.7 \\
\hline $\mathrm{Si}$ & 4.60 & 10.10 & 6.4 & 10.9 \\
\hline $\mathrm{P}$ & 0.21 & - & 0.36 & - \\
\hline S & 2.58 & 1.27 & 2.05 & - \\
\hline $\mathrm{Ca}$ & 69.94 & 71.50 & 62.15 & 71.84 \\
\hline $\mathrm{Ti}$ & 0.46 & 0.48 & 0.50 & 0.54 \\
\hline $\mathrm{V}$ & 0.12 & - & 0.11 & - \\
\hline $\mathrm{Cr}$ & 0.38 & - & 0.35 & - \\
\hline $\mathrm{Mn}$ & 1.56 & 0.93 & 1.58 & 1.26 \\
\hline $\mathrm{Fe}$ & 19.39 & 3.97 & 24.35 & 4.43 \\
\hline $\mathrm{Sr}$ & - & 0.11 & 0.07 & 0.12 \\
\hline
\end{tabular}
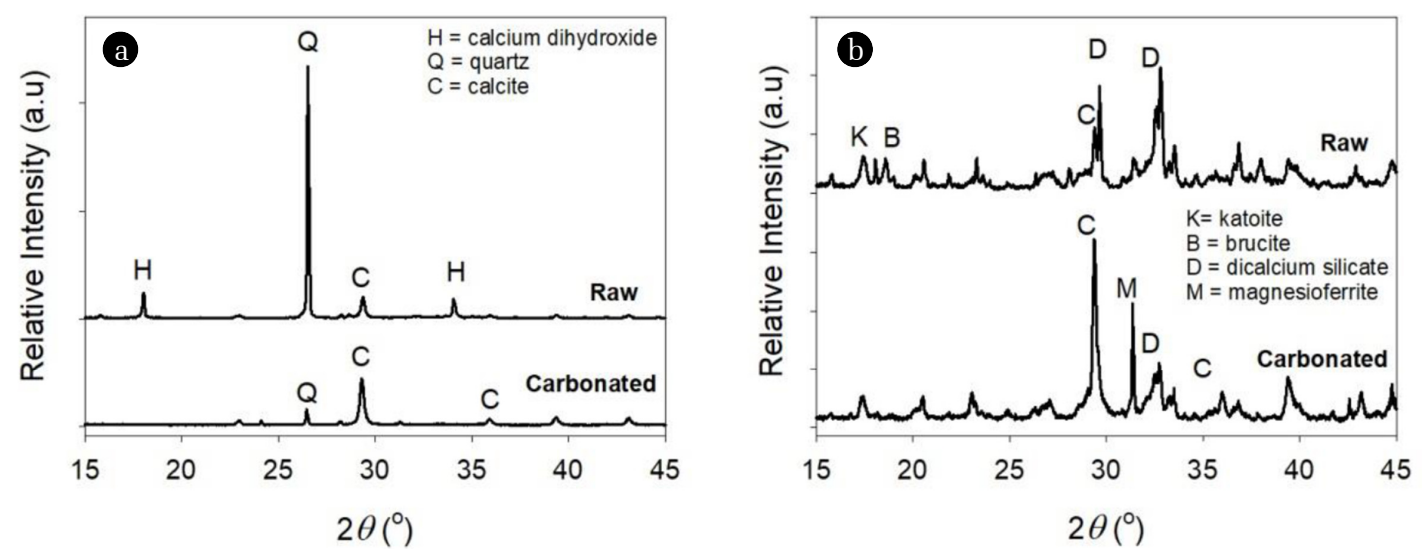

Fig. 2. The X-ray diffraction patterns of (a) BOF slag and (b) ladle slag before and after aqueous carbonation $\left(\mathrm{P}=10 \mathrm{bar}, \mathrm{T}=40^{\circ} \mathrm{C}, \mathrm{L} / \mathrm{S}\right.$ ratio $=5 \mathrm{~mL} / \mathrm{g}$-dry). $\mathrm{H}=$ calcium dihydroxide $\left(\mathrm{Ca}(\mathrm{OH})_{2}\right), \mathrm{Q}=$ quartz $(\mathrm{SiO} 2), \mathrm{C}=$ calcite $(\mathrm{CaCO} 3), \mathrm{K}=$ katoite $\left(\mathrm{Ca}_{3} \mathrm{Al}_{2}(\mathrm{OH})_{12}\right), \mathrm{B}=$ brucite $\left(\mathrm{Mg}(\mathrm{OH})_{2}, \mathrm{D}=\right.$ dicalcium silicate-gamma $\left(\mathrm{Ca}_{2} \mathrm{SiO}_{4}-\gamma\right)$ and $\mathrm{M}=$ magnesioferrite $\left(\mathrm{MgFe}_{2} \mathrm{O}_{4}\right)$.

respectively. The content of $\mathrm{CaCO}_{3}$ in carbonated $\mathrm{BOF}$ and ladle slags was approximately $5 \%$ and $9.3 \%$, respectively, as indicated by TGA, confirming that ladle slag exhibited higher $\mathrm{CO}_{2}$ uptake than BOF slag.

The ANC values of raw and carbonated slags were compared. As shown in Fig. 4, ANC of BOF and ladle slags decreased after carbonation. At $\mathrm{pH}$ 8.2, the ANC values of raw and carbonated BOF slags were 6.0 and $1.2 \mathrm{mmol} \mathrm{H}^{+} / \mathrm{g}$ slag, respectively, while those of raw and carbonated ladle slags were 5.0 and $2.0 \mathrm{mmol}$ $\mathrm{H}^{+} / \mathrm{g}$ slag, respectively. The change of ANC values for BOF slag was higher than that for ladle slag, indicating that carbonated ladle slag has higher $\mathrm{pH}$ buffering capability than carbonated BOF slag because of higher $\mathrm{CaCO}_{3}$ content of ladle slag [26].
Consequently, ladle slag has higher potential of $\mathrm{CO}_{2}$ sequestration with producing $\mathrm{CaCO}_{3}$, because ladle slag has higher Ca content, BET surface area, pore volume, pore size and $\mathrm{pH}$ buffering capacity than BOF slag as supported by several analytic methods such as BET, XRD, SEM, TGA and ANC tests.

\subsection{Effect of Carbonated Slag Amendment on the Immobilization of the Heavy Metals}

Effect of carbonated slag amendment on the immobilization of heavy metals in the field-contaminated soils was estimated by using TCLP and SM\&T extraction methods. The results of the extraction methods are summarized in Table 3 and 4, respectively. 

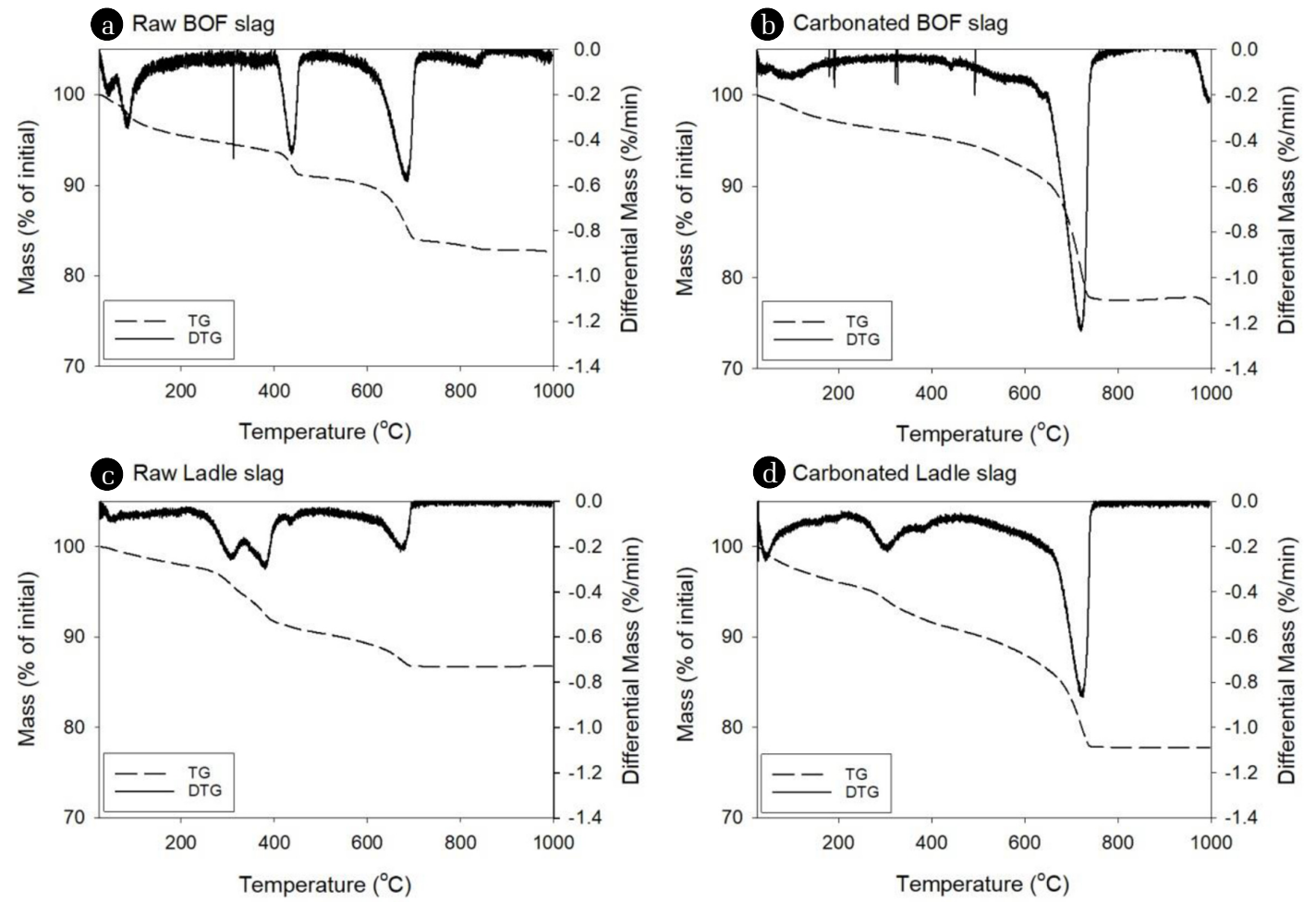

Fig. 3. Thermogravimetry (TG) and derivative thermogravimetry (DTG) diagrams of (a) raw BOF slag (b) carbonated BOF slag (c) raw ladle slag and (d) carbonated ladle slag. Slags were carbonated at $\mathrm{P}=10 \mathrm{bar}, \mathrm{T}=40^{\circ} \mathrm{C}$ and $\mathrm{L} / \mathrm{S}$ ratio $=5 \mathrm{~mL} / \mathrm{g}$-dry.

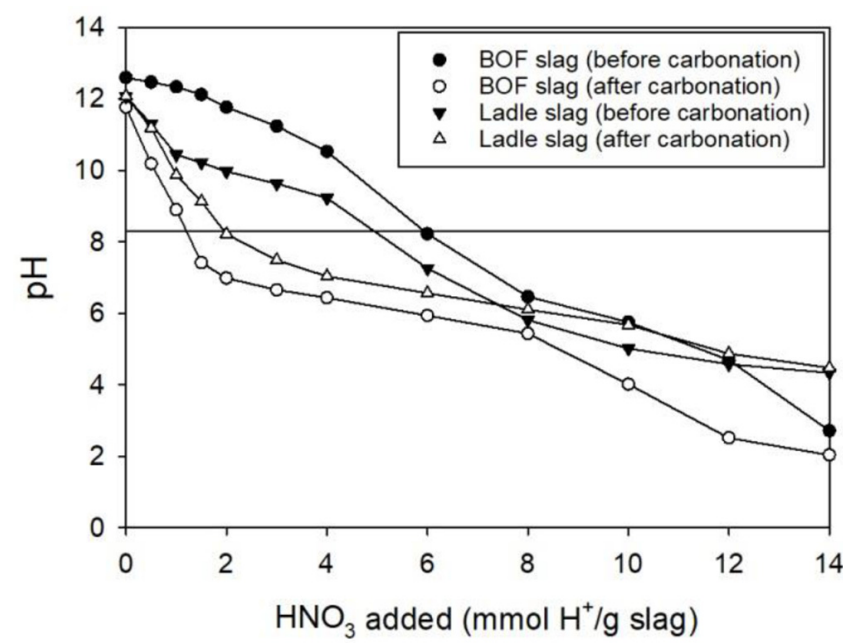

Fig. 4. Comparison of ANC before and after carbonation of BOF and ladle slags.

According to TCLP test, $\mathrm{Pb}, \mathrm{Cu}$ and $\mathrm{Zn}$ were the major contaminants in soils A and B. The highest TCLP-extractable heavy metals concentration observed was $75.2 \mathrm{mg} / \mathrm{L}$ of $\mathrm{Cu}$ in soil B. $\mathrm{Pb}$ concentrations in soils A and B (19.5 and $38.1 \mathrm{mg} / \mathrm{L}$, respectively) also exceeded USEPA-regulated limits ( $5 \mathrm{mg} / \mathrm{L}$ ), whereas Cd and Cr concentrations did not exceed the limits (see Table 3). TCLP extraction data for $\mathrm{Cu}, \mathrm{Ni}$ and $\mathrm{Zn}$ was also used to compare the immobilization efficiencies of these heavy metals in soils although they are not included in TCLP extraction regulation.

All immobilization treatments by using both raw and carbonated slags successfully led to decrease TCLP-extractable heavy metals concentrations for all soils (Table 3). For soil A, the TCLP-extractable $\mathrm{Pb}$ concentration was $19 \mathrm{mg} / \mathrm{L}$, surpassing the USEPA-regulated level of $5 \mathrm{mg} / \mathrm{L}$, whereas it decreased to less than $0.28 \mathrm{mg} / \mathrm{L}$ after immobilization with raw and carbonated slags (i.e., immobilization efficiency > 98\%). TCLP-extractable $\mathrm{Zn}$ also decreased from $29.4 \mathrm{mg} / \mathrm{L}$ in raw soil to less than 0.52 $\mathrm{mg} / \mathrm{L}$ after immobilization with raw and carbonated slags except for carbonated BOF slag (1.19 to $6.67 \mathrm{mg} / \mathrm{L}$ ). Cd, Cr, and Ni were not detected both before and after immobilization.

TCLP-extractable $\mathrm{Pb}$ concentration in soil $\mathrm{B}$ decreased from $38 \mathrm{mg} / \mathrm{L}$ in raw soil to 0.31 and $0.77 \mathrm{mg} / \mathrm{L}$ after immobilization using raw and carbonated ladle slags, respectively, while the use of raw and carbonated BOF slag resulted in the decrease to 4.58 and $5.20 \mathrm{mg} / \mathrm{L}$, respectively. $\mathrm{Cd}, \mathrm{Cr}, \mathrm{Cu}, \mathrm{Ni}$, and $\mathrm{Zn}$ were well retained after immobilization with their TCLP-extractable concentrations decreased to below $0.55 \mathrm{mg} / \mathrm{L}$.

Table 4 presents SM\&T results in the exchangeable, reducible, oxidizable, and residual heavy metals fractions in soils $\mathrm{A}$ and $\mathrm{B}$, after immobilizing using raw and carbonated BOF and ladle slags, respectively. The exchangeable fraction (step 1) generally decreased whereas the residual fraction (step 4) increased after immobilization with raw and carbonated slags.

The difference between using raw and carbonated slags was not noticeable for soil A while the fractionation of soil B contaminated 


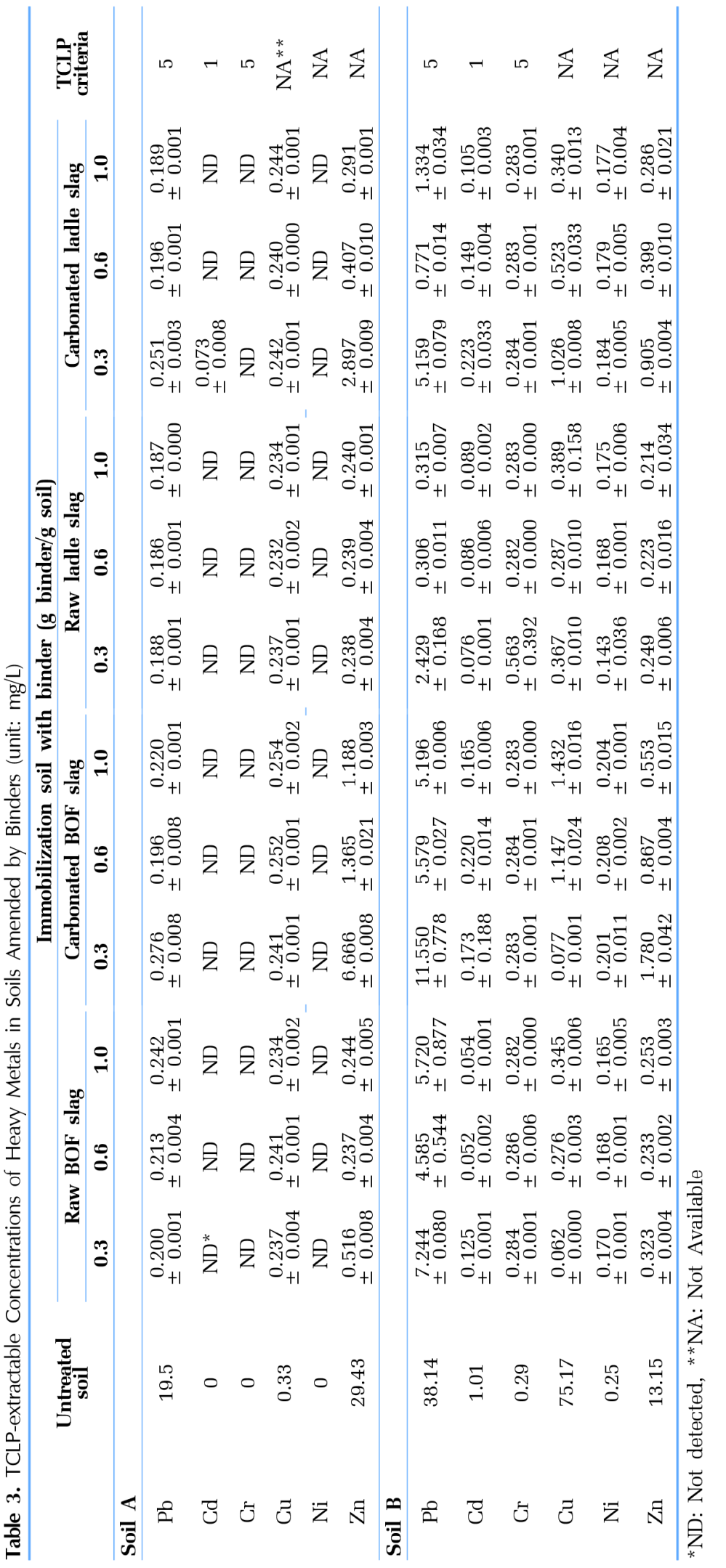

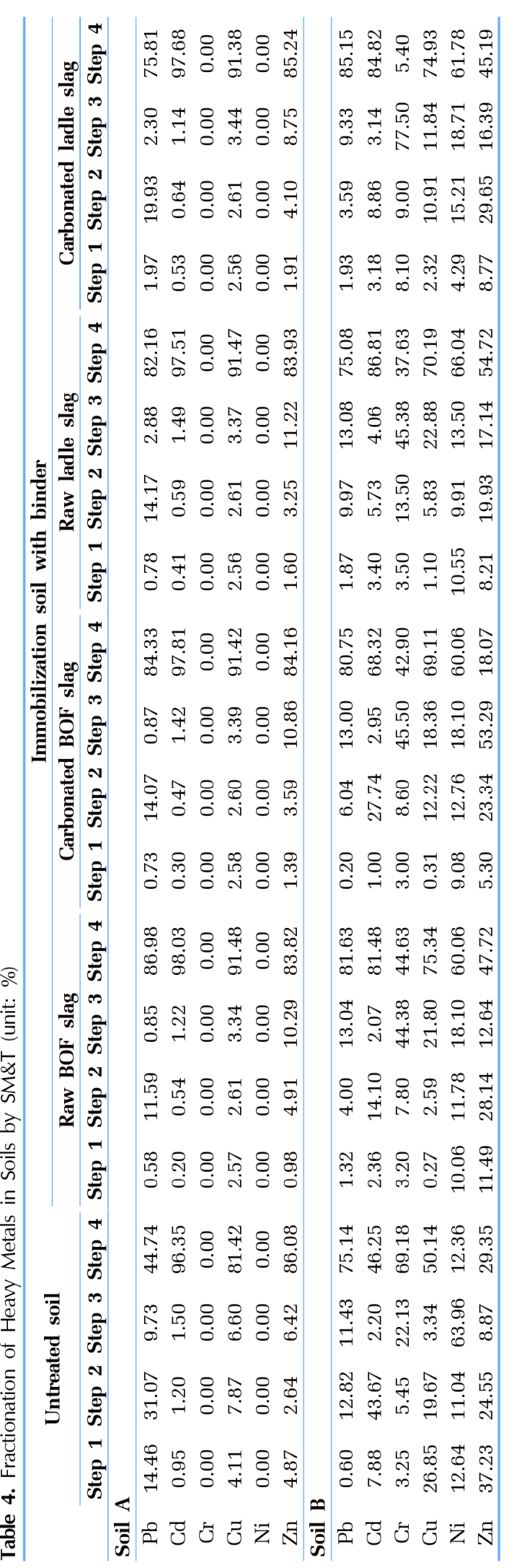


by higher concentrations of heavy metals showed that raw slags performed better than carbonated ones. This observation is explained by the fact that the immobilization is affected by soil $\mathrm{pH}$, with the use of raw slag resulting in a higher $\mathrm{pH}$ compared to the use of carbonated slag. This is because of the decrease in $\mathrm{pH}$ buffer capacity as $\mathrm{OH}^{-}$concentrations decreased during carbonation. The decrease in TCLP-extractable concentrations was due to the pozzolanic reaction where $\mathrm{Ca}$ in the slag was reacted with silica $\left(\mathrm{SiO}_{2}\right)$ present in the soils to form C-S-H (Ca-Si-OH) gel that is responsible for the development of binding force [39] and the formation of additional calcite [40]. Calcite formed by carbonation and addition of slag seals the soil pores, resulting in preventing heavy metals leaching [40, 41]. Makhloufi et al. [42] also reported that calcium present in slags can form C-S-H gel during hydration due to the pozzolanic reaction. Carbonated slag generally has less Ca available for the pozzolanic reaction due to consumption of calcium hydroxide by $\mathrm{CO}_{2}$ binding in the preceding carbonation.

$$
\mathrm{Ca}(\mathrm{OH})_{2}+\mathrm{SiO}_{2}+0.5 \mathrm{H}_{2} \mathrm{O} \rightarrow \mathrm{CaO} \cdot \mathrm{SiO}_{2} \cdot 1.5 \mathrm{H}_{2} \mathrm{O}
$$

\section{Conclusions}

The applicability of BOF and ladle slags for $\mathrm{CO}_{2}$ carbonation and the immobilization efficiencies of heavy metals between raw and the carbonated slags were investigated. For higher capacity of aqueous carbonation, high pressure (5 atm), high temperature $\left(40^{\circ} \mathrm{C}\right)$ and high $\mathrm{L} / \mathrm{S}$ ratio (L/S $=5 \mathrm{~mL} / \mathrm{g}$-dry) were required. The maximum carbonated concentrations of $\mathrm{CO}_{2}$ in slags were 0.584 and $1.038 \mathrm{mmol} / \mathrm{g}$ of BOF and ladle slags, respectively. The physicochemical characteristics of slags including BET surface area pore volume and size, Ca contents, and $\mathrm{pH}$ buffering capacity affected the efficiency of $\mathrm{CO}_{2}$ carbonation.

The immobilization efficiencies of heavy metals with raw and carbonated slags were also evaluated by TCLP and SM\&T procedures. The results of the leaching tests showed no effect of carbonation on the immobilization because of high calcium content (as $\mathrm{CaO}$ and $\mathrm{Ca}(\mathrm{OH})_{2}$ ) in slags. According to TLCP results, the extractable concentrations of heavy metals were varied irregularly with characteristics of soils, before and after carbonation, and dosage ratio of slag to soil. It should be noted that extractable concentrations of several heavy metals such as $\mathrm{Zn}$ and $\mathrm{Pb}$ allowed increasing after carbonation whereas other heavy metals did not have the same results. SM\&T analyses also showed the unsystematic correlation in exchangeable and residual fractions between the raw and carbonated slags. In summary, although a clear correlation between TCLP and SM\&T results and the physicochemical properties of soils and slags were not found, the results implicates that carbonated slag have benefits of heavy metals immobilization as well as $\mathrm{CO}_{2}$ storage.

\section{Acknowledgments}

This work was supported by Korea Environment Industry \&
Technology Institute(KEITI) through Subsurface Environmental Management(SEM) Projects, funded by Korea Ministry of Environment(MOE)(2019002480005) and partially by Basic Science Research program through the National Research Foundation of Korea (NRF) funded by the Ministry of Education (\#2016R1D1A3 B03935482).

\section{References}

1. Proctor DM, Fehling KA, Shay EC, et al. Physical and chemical characteristics of blast furnace, basic oxygen furnace, and electric arc furnace steel industry slags. Environ. Sci. Technol. 2000;34:1576-1582.

2. Rađenović A, Malina J, Sofilić T. Characterization of ladle furnace slag from carbon steel production as a potential adsorbent. Adv. Mater. Sci. Eng. 2013;2013:1-6.

3. Worldsteel Association. Steel industry by-products. Worldsteel Association Publishing Fact sheet [Internet]. c2016 [cited June 2016]. Available from: https://www.worldsteel.org/publications/ fact-sheets.html.

4. Shi C. Characteristics and cementitious properties of ladle slag fines from steel production. Cem. Concr. Res. 2002;32:459-462.

5. Doucet FJ. Effective $\mathrm{CO}_{2}$-specific sequestration capacity of steel slags and variability in their leaching behavior in view of industrial mineral carbonation. Miner. Eng. 2010;23:262-269.

6. Sanna A, Uibu M, Caramanna G, Kuusik R, Maroto-Valer MM. A review of mineral carbonation technologies to sequester $\mathrm{CO}_{2}$. Chem. Soc. Rev. 2014;43:8049-8080.

7. Pan SY, Chiang PC, Chen YH, Chen CD, Lin HY, Chang EE. Performance evaluation of aqueous carbonation for steel making slag: Process chemistry. Energ. Procedia 2013;37:115-121.

8. Polettini A, Pomi R, Stramazzo A. $\mathrm{CO}_{2}$ sequestration through aqueous accelerated carbonation of BOF slag: A factorial study of parameters effects. J. Environ. Manage. 2016;167:185-195.

9. Uibu M, Kuusik R, Andreas L, Kirsimae K. The $\mathrm{CO}_{2}$-binding by Ca-Mg-silicates in direct aqueous carbonation of oil shale ash and steel slag. Energ. Procedia 2011;4:925-932.

10. Montes-Hernandez G, Pérez-López R, Renard F, Nieto J, Charlet L. Mineral sequestration of $\mathrm{CO}_{2}$ by aqueous carbonation of coal combustion fly-ash. J. Hazard. Mater. 2009;161:1347-1354.

11. Bernal SA, Nicolas RS, Provis JL, de Gutiérrez RM, van Deventer JSJ. Natural carbonation of aged alkali-activated slag concretes. Mater. Struct. 2014;47:693-707.

12. Bernal SA. Effect of the activator dose on the compressive strength and accelerated carbonation resistance of alkali silicate-activated slag/metakaolin blended materials. Constr. Build. Mater. 2015;98:217-226.

13. Ukwattage NL, Ranjith PG, Li X. Steel-making slag for mineral sequestration of carbon dioxide by accelerated carbonation. Measurement 2017;97:15-22.

14. Bade R, Oh S, Shin WS. Assessment of metal bioavailability in smelter-contaminated soil before and after lime amendment. Ecotoxicol. Environ. Saf. 2012;80:299-307.

15. Capobianco O, Costa G, Thuy L, Magliocco E, Hartog N, Baciocchi R. Carbonation of stainless steel slag in the context of in situ Brownfield remediation. Miner. Eng. 2014;59:91-100. 
16. Kim GM, Jang JG, Naeem F, Lee HK. Heavy metal leaching, $\mathrm{CO}_{2}$ uptake and mechanical characteristics of carbonated porous concrete with alkali-activated slag and bottom ash. Int. J. Concr. Struct. Mater. 2015;9:283-294.

17. Lee SH, Lee JS, Choi YJ, Kim JG. In situ stabilization of cadmium-, lead-, and zinc-contaminated soil using various amendments. Chemosphere 2009;77:1069-1075.

18. Liu J, Xu D, Xiong L, Hills C, Carey P, Gardner K. Comparison of properties of traditional and accelerated carbonatedsolidified/stabilized contaminated soils. J. Environ. Sci. 2008;20:593-598.

19. MOE. Primary investigation of soil pollution for metalliferous abandoned mines in 2010 (in Korean). Final Report of Ministry of Environment. 2010.

20. Tae S-J. Immobilization of $\mathrm{Cr}(\mathrm{VI})$ in stainless steel slag and $\mathrm{Cd}$, As, and $\mathrm{Pb}$ in wastewater using blast furnace slag via a hydrothermal treatment. Met. Mater. Int. 2017;23:576-581.

21. Chen M, Ma LQ. Comparison of three aqua regia digestion methods for twenty florida soils. Soil Sci. Soc. Am. J. 2001;65: 491-499.

22. Santos RM, Mertens G, Salman M, Cizer Ö, Gerven TV. Comparative study of aging, heat treatment and accelerated carbonation for stabilization of municipal solid waste incineration bottom ash in view of reducing regulated heavy metal/metalloid leaching. J. Environ. Manage. 2013;128:807-821.

23. Ho YS, McKay G. The kinetics of sorption of divalent metal ions onto sphagnum moss peat. Water Res. 2000;34:735-742.

24. Oh S, Wang Q, Shin WS, Song DI. Sorption and desorption of PAHs in coastal sediment. Korean J. Chem. Eng. 2013;30: 145-153.

25. Smith JM, Van Ness HC, Abbott MM. Introduction to chemical engineering thermodynamics. 7th ed. New York: McGraw-Hill 2004.

26. Gurtubay L, Gallastegui G, Elias A, Rojo N, Barona A. Accelerated aging of an EAF black slag by carbonation and percolation for long-term behavior assessment. J. Environ. Manage. 2014;140:45-50.

27. Chen Q, Zhang L, Ke Y, Hills C, Kang Y. Influence of carbonation on the acid neutralization capacity of cements and cement-solidified/stabilized electroplating sludge. Chemosphere 2009;74: 758-764.

28. Shwabkeh RA, Tutunji MF. Experimental study and modeling of basic dye sorption by diatomaceous clay. Appl. Clay Sci. 2003;24:111-120.

29. USEPA. Method 1311: Toxicity characteristic leaching procedure. In: Test methods for the evaluation of solid waste: Laboratory manual physical chemical methods. SW-846. Washington D.C.: Office of Solid Waste; 2007.

30. Quevauviller Ph, Rauret G, López-Sánchez J-F, Rubio R, Ure
A, Muntau H. Certification of trace metal extractable contents in a sediment reference material (CRM 601) following a three-step sequential extraction procedure. Sci. Total Environ. 1997;205:223-234.

31. Rauret G, López-Sánchez J-F, Sahuquillo A, et al. Application of a modified BCR sequential extraction (three-step) procedure for the determination of extractable trace metal contents in a sewage sludge amended soil reference material (CRM 483), complemented by a three-year stability study of acetic acid and EDTA-extractable metal content. J. Environ. Monit. 2000; 2:228-233

32. Carroll JJ, Slupsky JD, Mather AE. The solubility of carbon dioxide in water at low pressure. J. Phys. Chem. Ref. Data 1991;20:1201-1209.

33. Huijgen WJ, Witkamp GJ, Comans RNJ. Mineral $\mathrm{CO}_{2}$ sequestration by steel slag carbonation. Environ. Sci. Technol. 2005;39: 9676-9682.

34. Salman M, Cizer Ö, Pontikes Y, et al. Effect of accelerated carbonation on AOD stainless steel slag for its valorization as a $\mathrm{CO}_{2}$-sequestering construction material. Chem. Eng. J. 2014;246:39-52

35. Ko MS, Chen YL, Jiang JH. Accelerated carbonation of basic oxygen furnace slag and the effects on its mechanical properties. Constr. Build. Mater. 2015;98:286-293.

36. Baciocchi R, Costa G, Polettini A, Pomi R. Influence of particle size on the carbonation of stainless steel slag for $\mathrm{CO}_{2}$ storage. Energy Procedia 2009;1:4859-4866.

37. Boone MA, Nielsen P, Kock TD, Boone MN, Quahebeur M, Cnudde V. Monitoring of stainless-steel slag carbonation using X-ray computed microtomography. Environ. Sci. Technol. 2014; 48:674-680.

38. Chang E, Chen C, Chen Y, Pan S, Chiang P. Performance evaluation for carbonation of steel-making slags in a slurry reactor. J. Hazard. Mater. 2011;186:558-564.

39. Li F, Bade R, Oh S, Shin WS. Immobilization of heavy metals in a contaminated soil using organic sludge char and other binders. Korean J. Chem. Eng. 2012;29:1362-1372.

40. Singh TS, Pant KK. Solidification/stabilization of arsenic containing solid wastes using portland cement, fly ash and polymeric materials. J. Hazard. Mater. 2006;131:29-36.

41. Bertos MF, Simons SJR, Hills CD, Carey PJ. A review of accelerated carbonation technology in the treatment of cement-based materials and sequestration of $\mathrm{CO}_{2}$. J. Hazard. Mater. 2004;112: 193-205.

42. Makhloufi Z, Chettih M, Bederina M, Kadri EIH, Bouhicha M. Effect of quaternary cementitious systems containing limestone, blast furnace slag and natural pozzolan on mechanical behavior of limestone mortars. Constr. Build. Mater. 2015;95: 647-657. 